\title{
Ownership Structure, Capital Structure and Firm Performance: A Case in Indonesia
}

\author{
Rosyeni Rasyid ${ }^{1}$, Muthia Roza Linda ${ }^{2}$ \\ ${ }^{1}$ Universitas Negeri Padang, Padang, Indonesia, $₫$ Rosyenirasyid@yahoo.com \\ 2 Universitas Negeri Padang, Padang, Indonesia, $₫$ muthia_rozalinda@yahoo.com
}

\begin{abstract}
This paper aims to investigate the significant relationships among ownership sructure (including institutional ownership and insider ownership), capital structure and performance of thirty manufacturing companies listed in Indonesia Stock Exchange from 2010 to 2016. Firm performance was measured by ROA, MBV and Tobin's q. We used panel data regression with 210 observations. The results showed that there was a significant relationship between institutional ownership and performance measured by MBV and Tobin's q, but it was not significant when measured by ROA. Meanwhile, there was no significant relationship between insider ownership and performance measured by ROA, $M B V$ and $Q$ ratio. The results illustrated that ROA was negatively influenced by capital structure, but MBV and $\mathrm{Q}$ ratio were not influenced by capital structure. Furthermore, liquidity as the control variable had positive effect on ROA. Econ/ /omic growth had positive effect on firm performance although firm size had no effect on firm performance.
\end{abstract}

Keywords: institutional ownership, insider ownership, capital structure, firm performance

\section{Introduction}

Firm performance is information that is very important for investors as a basis for consideration in stock investment activities. Firm performance is the result of decisions taken by a manager in running a company. There are two approaches that are often used in research to measure firm performance, namely accounting based and market based (Al-Matari, et.al, 2014). Accounting based measures the performance of a company in terms of firm financial performance using analysis of firm financial statements. The financial ratio that is most frequently used in performance measurement and research is return on assets (ROA). Return on assets is often used because this ratio is able to reflect the effectiveness of a company in using the assets in order to carry out the economic interests of shareholders ( Ibrahim \& Samad, 2011). Furthermore, market based is a market-based performance measurement that represents future aspects and reflects the expectations of shareholders regarding the firm future performance, which has a basis for previous performance or current performance (Wahla, Shah, \& Hussain, 2012). This market-based firm performance measurement is carried out to determine the value of a company. Good firm value represents future prospects that will attract investors.

The relationship between ownership structure and firm performance, up to now, remains the center of studies in financial management, especially in the conceptual framework of agency theory. This is due to the separation between firm ownership and firm control. This analysis adds to the understanding of the complexity of governance model and impacts on firm strategy (Collin et al., 2013). Weak firm performance and firm governance will be related to ownership structure. However, the results of the existing studies have revealed diverse results, either for the concentration of ownership or shareholder ownership, on firm performance (Kapopoulos and Lazaretou, 2007; Saona and San Martin, 2016). The proportion of share ownership can illustrate a good firm performance so this will increase the signals of investors to invest in the company (Bayrakdaroglu et al., 2012). A study conducted by (Mc Connell and Servaes, 1990; Hermalin and Weisbach, 1991 Douma et al, 2003; Bayrakdaroglu et al, 2012) revealed that the increase in the shareholding structure would always go hand in hand with the increase in profits generated and the increase in firm value. However, it has 
not much known about the relationship between ownership structure and firm performance in the developing countries after the economic crisis in America in 2008 which impacted the capital markets throughout the world including Indonesia. Therefore, the JCI (Composite Stock Price Index) declined. Demsetz (1983) argues that certain ownership structures apply as long as they prove profitable. Thus, the changes in firm ownership that emerged after the crisis and post-transition resulted from privatization, systemic reform (Yeoh, 2007, Darwazeh et al, 2018) and the rise of newly established companies (Dobak, 2006) are expected to represent evolution structure to create and capture better firm performance and greater firm value (Jones et al., 2005).

One of the important decisions that must be made by a manager is the decision concerning the composition of the source of funds to be used by the company, also called capital structure decision. Capital structure is a framework that describes how equity and debt are used to finance firm operations to produce optimal returns for shareholders and to maximize firm returns by taking into account the level of risk (Dada \& Ghazali, 2016). Capital structure has been considered one of the most important factors in firm financing policy because of its very important role in firm performance (Gambo, Ahmad \& Musa, 2016). According to Akintoye (2016) capital structure decision is important for each business arising from the need to maximize the wealth of business stakeholders and the fact that the decision has a significant impact on firm ability to compete in competitive atmosphere (Gambo, Ahmad \& Musa, 2016). The relationship between capital structure and firm performance is one that has received substantial attention in financial literature. There are several reasons that make capital structure important, one of which is because the level of firm debt has increased significantly over the past few periods and requires an explanation of the impact of the level of debt on firm performance. A company can maintain the mixture of debt and equity, but the problem is whether the proportion of debt and equity has the benefits greater than the costs. This is a problem that must be answered because different financial sources have different cost and benefit structures; the same thing happens with various types of debt instruments (Khan, 2012) and (Amjed, 2011).

Several empirical studies have been conducted to explore whether there is a relationship (positive, negative or no relationship) between debt policy and firm performance. Studies conducted by Majumdar and Chhibber (1999), Chiang et al. (2002), Gleason et al (2000), Onaolapo and Kajola (2010), Sadeghian et al. (2012), (Goddard, Tavakoli, \& Wilson, 2005), Rao et al. (2007), Nunes, Serrasqueiro, \& Sequeira, (2007), and Singh \& Singh ( 2016) found negative relationship between firm policy and firm performance. On the other hand, Ghosh et al., (2000), Hadlock and James,(2002), Margaritis and Psillaki, (2010), Abor, (2005), Kyereboah-Coleman, (2007), Gill \& Nahum (2011) , Pratheepan \& Banda, (2016) and Nenu et.al (2018), found positive impact of capital structure on firm performance. In addition, Hung et.al (2002), Ebaid (2009) and Singh \& Singh (2018) found no statistical significant relationship between firm capital structure and firm value.

The manufacturing industries have profitable prospects, because they generate foreign exchange which is a source of funds for development and economic growth in Indonesia. The manufacturing sector is chosen by investors as their choice to invest. This is due to achievements achieved by each sub-sector. With a large population, the manufacturing sector is the engine of economic growth in Indonesia. According to Harjanto as Director General of the Manufacturing Industry Base of the Ministry of Industry of the Republic of Indonesia, in 2015 the government has a strengthening target in the manufacturing industry sector which is considered to have enormous potential (Dissecting Industrial Potential in Indonesia) (Harjanto, 2015). However, in reality the companies do not always experience an increase in firm performance, both financial performance and market value performance. This shows that the manufacturing sector is experiencing a decline due to the economic stability. This study explored the impact of ownership structure and capital structure on firm performance. This is because many companies in Indonesia are controlled by families or controlling shareholder groups (Claessens, Djankov and Lang, 2000; Zhuang, Edwards and Capulong, 2001; Claessens and Fan, 2002), and this will influence the managers in making debt policy, which in turn can affect firm performance. Based on this condition, this study examined the influence of ownership structure and debt policy on the performance of manufacturing companies listed on the Indonesia 
Stock Exchange. Manufacturing companies were chosen because manufacturing companies play an important role in economic growth and were considered the leading sector for other sectors. In addition, the manufacturing industry is a category of companies on the IDX that has the opportunity to grow and develop rapidly because of its growing market potential from year to year along with the level of the needs of Indonesian population.

Based on the described above, The hypothesis of this research are $H_{1}$ : Managerial ownership has a positive impact on firm financial performance

$\mathrm{H}_{2}$ : Managerial ownership has a positive impact on firm value

$\mathrm{H}_{3}$ : Institutional ownership has a positive impact on firm financial performance

$\mathrm{H}_{4}$ : Institutional ownership has a positive impact on firm value

$H_{5}$ : Capital structure has a significant impact on firm financial performance

$H_{6}$ : Capital structure has a significant impact on firm value

\section{Conceptual framework}

Based on the explanation of the theoretical literature and the results of previous relevant studies, the conceptual framework of this study can be seen in the following figure:

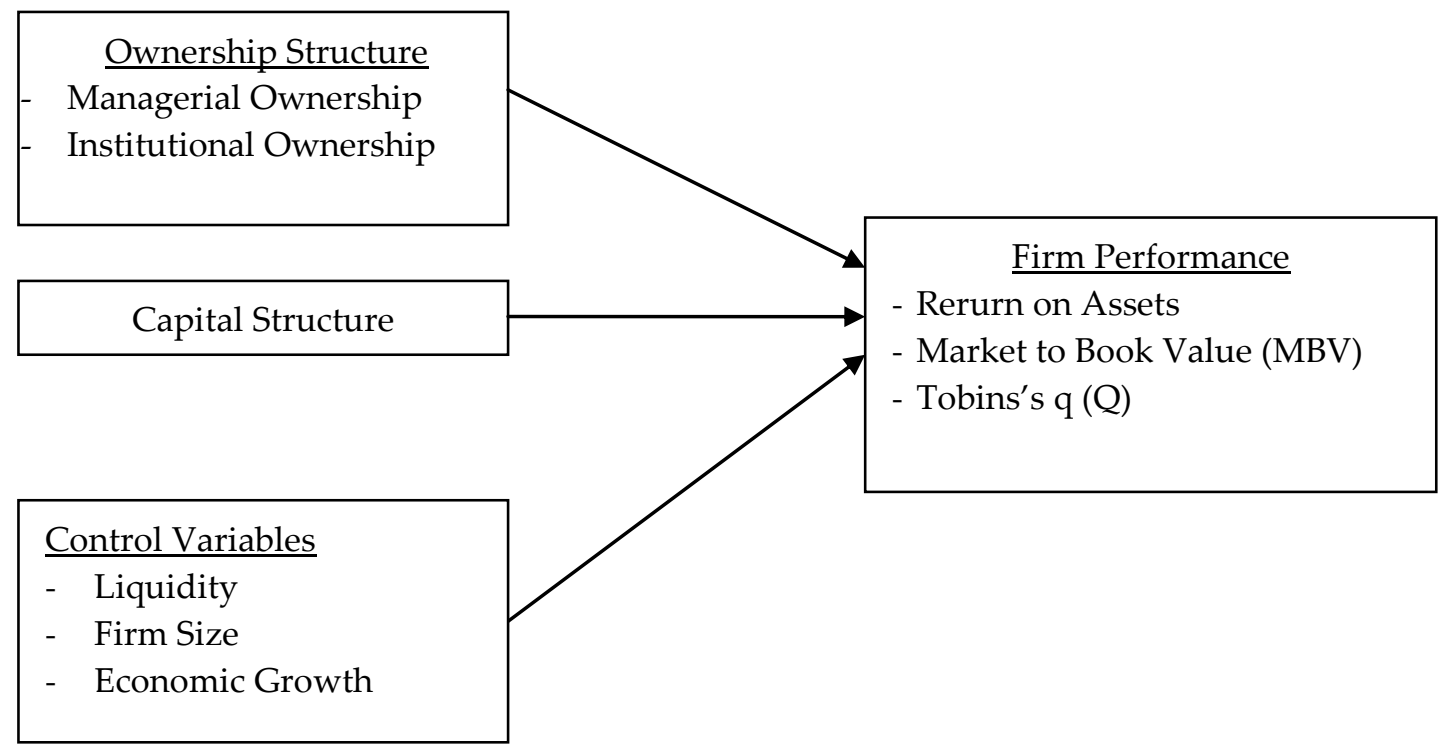

Figure 1 Conceptual Framework

\section{Methods}

This study used panel data from manufacturing companies listed on the Indonesia Stock Exchange in the period 2010 to 2016 with the criteria that the companies had institutional ownership and managerial ownership during 2010-2016, and had complete financial data. Based on these criteria, 30 companies were acquired, with 210 observations. The data were obtained from the data published on the official website of the Indonesia Stock Exchange (www.idx.co.id). This study chose the period 2010-2016 because this period did not capture the Asian financial crisis. The motivation was in order that the results would not be disturbed by the impact of the financial crisis in the regions.

This study used dependent variable, independent variables, and control variables. The dependent variable in this study is firm performance measured by using financial performance and firm market value performance. Financial performance was measured by return on assets (ROA), while market value performance was measured using Tobins' $(\mathrm{Q})$ and market book value $(\mathrm{MBV})$. The independent variables in this study are ownership structure in the forms of managerial ownership and institutional 
ownership and capital structure. Meanwhile, the control variables are liquidity, firm size, and economic growth. STATA 13.0 was used for the analyses.

\section{Research model}

This study used dependent variable in the form of financial performance using three measurement models, namely ROA, MBV, Q. Regression equation models of this study are as follows:

1. $R O A_{i . t}=\alpha_{0}+\beta_{1} \mathrm{DER}+\beta_{2} \mathrm{INSDR}+\beta_{3} \mathrm{INST}++\beta_{4} \mathrm{LIQ}+\beta_{5} \mathrm{SIZE}+\beta_{6} \mathrm{GDP}+\varepsilon_{i . t}$

2. $M B V_{i . t}=\alpha_{0}+\beta_{1} \mathrm{DER}+\beta_{2} \mathrm{INSDR}+\beta_{3} \mathrm{INST}++\beta_{4} \mathrm{LIQ}+\beta_{5} \mathrm{SIZE}+\beta_{6} \mathrm{GDP}+\varepsilon_{i . t}$

3. Tobins $Q_{i t}=\alpha_{0}+\beta_{1}$ DER $+\beta_{2}$ INSDR $+\beta_{3}$ INST $++\beta_{4} \mathrm{LIQ}+\beta_{5} \mathrm{SIZE}+\beta_{6} \mathrm{GDP}+\mathrm{E}_{i . t}$

\section{Results and Discussion}

The initial sample $(\mathrm{N})$ in this study consisted of 30 companies. Observations had been done for 7 years with the total of 210 observations. According to Hair et al (2010, p.66) z-score value $>2.5$ for a small number of samples ( $<80$ cases) is considered outlier, while for a large number of samples z-score value $>4$ is considered outlier (Latan, 2014). Based on the results of the data processed by the STATA program, for the number of samples $>80$ there were 12 observations considered outlier, so the final sample $(\mathrm{N})$ of this study were 198 observations. Table 1 reports descriptive statistics on the variables used in the subsequent analysis.

Table 1 Descriptive Statistics

\begin{tabular}{lcccc}
\hline & Mean & Std.Dev & Minimum & Maximum \\
\hline Return on assets (ROA) & 0.045 & 0.067 & -0.097 & 0.262 \\
\hline Market book value (MBV) & 1.392 & 1.121 & 0.060 & 5.970 \\
\hline Tobins's q (Q) & 1.314 & 0.797 & 0.338 & 4.253 \\
\hline Insider ownership (Insdr) & 0.042 & 0.057 & 0.0001 & 0.231 \\
\hline Instititional ownership (Inst) & 0.482 & 0.256 & 0.011 & 0.900 \\
\hline Capital structure (DER) & 1.214 & 1.088 & 0.104 & 6.013 \\
\hline Liquidity (Liq) & 2.179 & 1.661 & 0.449 & 10.684 \\
\hline Firm size (Size) & 14.29 & 1.829 & 11.141 & 18.289 \\
\hline Economic growth (GDP) & 0.563 & 0.006 & 0.048 & 0.065 \\
\hline
\end{tabular}

Source : Statistical analysis results (2019)

Table 1 contains a summary of descriptive statistics for 30 sample companies with 210 observations. Firm performance was dependen variable with the indicators of ROA, MBV, and Tobin's q. ROA has mean 4.5\%, MBV has mean 1.392, and Tobin's q has mean 1.314 .

\section{Hypothesis Testing}

Before testing the hypotheses, the best selection of estimation models on common effects, fixed effects, and random effects was carried out. To see whether the models followed the fixed effects or the common effects, F Redundant Test was carried out. After Redundant F test was done to select the model, common effect or fixed effect, it turned out that the data panel model that was in accordance with the characteristics of the research data was fixed effect. Meanwhile, to determine the best model, fixed effect or random effect, Hausman test was used. In fact, the result showed that the data panel model that was in accordance with the characteristics of the research data was random effect model. Table 2 follows the results of Hausman test as a reinforcement of the model used. 
Table 2 Hausman Test

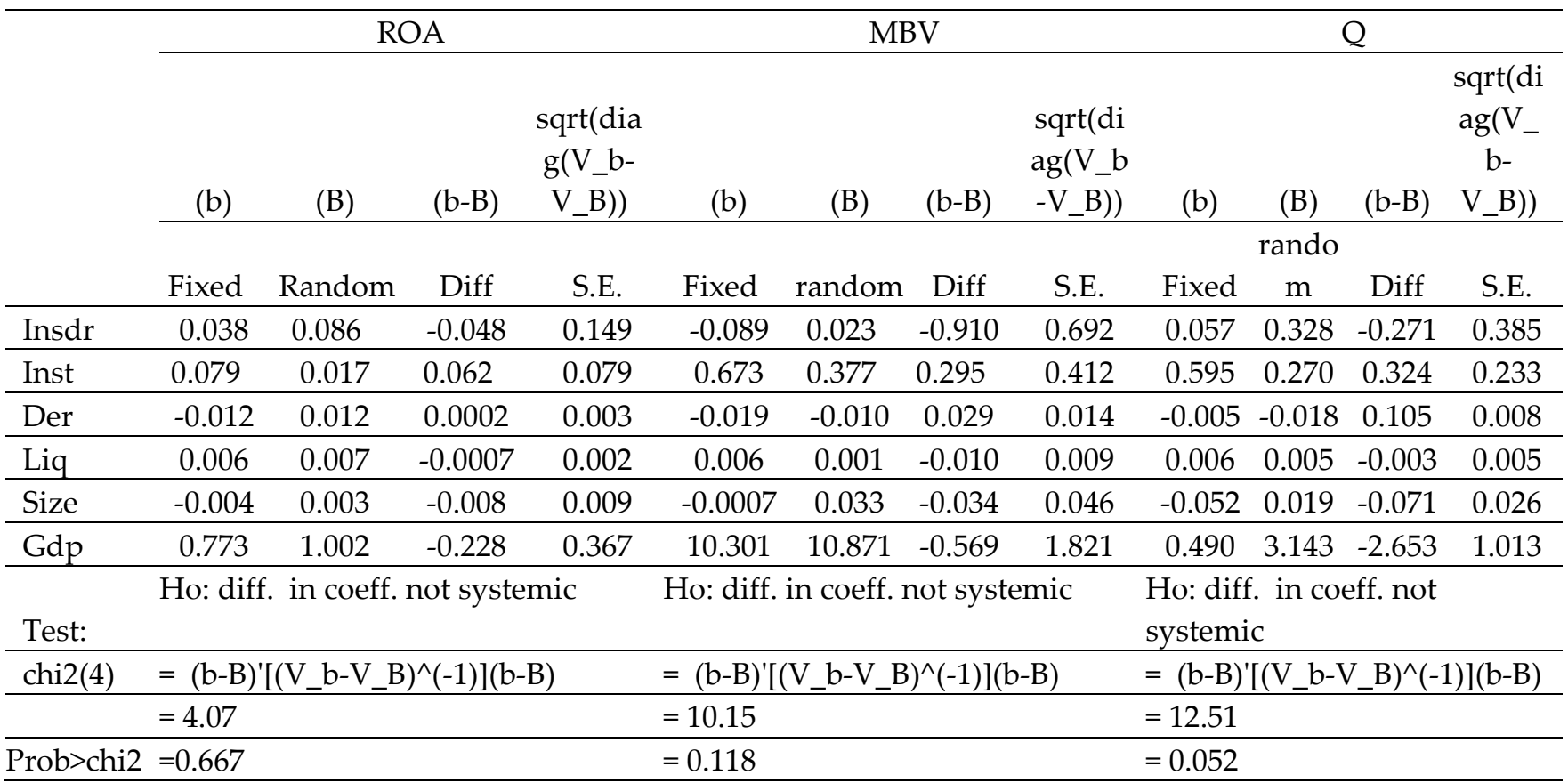

Source : Statistical analysis results (2019)

Based on the results of Hausman test seen in Table 2, the chi-square probability value was bigger than the significance level $(\alpha=0.05)$, so better estimation model was the Random Effect model. The following are the results of panel data regression using the Random Effect model displayed in Table

Table 3 The Estimation Results of Panel Data

\begin{tabular}{|c|c|c|c|c|c|c|c|c|c|c|c|c|}
\hline & \multicolumn{4}{|c|}{ ROA } & \multicolumn{4}{|c|}{ MBV } & \multicolumn{4}{|c|}{ TOBINS'Q } \\
\hline & Coef. & SE & $\mathrm{z}$ & $P>|z|$ & Coef. & SE. & $\mathrm{z}$ & $P>|z|$ & Coef. & SE. & $\mathrm{z}$ & $P>|z|$ \\
\hline \multicolumn{13}{|l|}{ _cons } \\
\hline & -0.383 & 0.062 & -6.13 & 0.000 & 1.268 & 0.496 & -2.55 & 0.011 & -0.497 & 0.292 & -1.70 & 0.089 \\
\hline Insdr & 0.086 & 0.092 & 0.93 & 0.352 & 0.022 & 0.697 & 0.03 & 0.974 & 0.328 & 0.407 & 0.81 & 0.420 \\
\hline Inst & 0.017 & 0.023 & 0.74 & 0.462 & 0.378 & 0.198 & 1.90 & 0.057 & 0.270 & 0.117 & 2.30 & 0.021 \\
\hline Der & -0.012 & 0.004 & -2.98 & 0.003 & -0.010 & 0.026 & -0.39 & 0.698 & -0.015 & 0.015 & -1.00 & 0.317 \\
\hline Liq & 0.007 & 0.002 & 2.53 & 0.011 & 0.001 & 0.018 & 0.08 & 0.936 & $-0,005$ & 0.011 & -0.49 & 0.626 \\
\hline Size & 0.004 & 0.003 & 1.03 & 0.301 & 0.033 & 0.028 & 1.20 & 0.228 & -0.018 & 0.016 & 1.14 & 0.255 \\
\hline Gdp & 1.002 & 0.447 & 2.24 & 0.025 & 10.871 & 2.678 & 4.06 & 0.000 & 3.143 & 1.544 & 2.04 & 0.042 \\
\hline R-sq overall & 0.23 & & Prob > & ii2 0.000 & 0.10 & & Prob > & hi2 0.001 & 0.02 & & Prob > chi2 & 20.084 \\
\hline
\end{tabular}

Source : Statistical analysis results (2019)

\section{The Effect of Managerial Ownership on Firm Performance}

Based on the results of the study, it was found that managerial ownership (INSDR) had no effect on firm performance both on profitability and on firm value in the manufacturing companies listed on the IDX. It means that the changes that occur in managerial ownership of a company, either an increase or a decrease in ownership, do not affect firm performance. The result of this study is in line with studies supported by (Demsetz \& Villalonga, 2001; Obembe, Olaniyi, \& Soetan, 2016) who found that managerial share ownership did not have a positive impact on firm performance. Sujoko and Soebiantoro (2007) explain that there is no influence between managerial ownership and firm performance because management does not have control of the company. It is controlled more by majority shareholders so that management is only an extension of the majority shareholders. Managerial ownership does not affect firm value, possibly because the percentage of share ownership 
held by a manager in the manufacturing companies listed on the Indonesia Stock Exchange is too small. The average percentage of managerial party ownership is $4.1 \%$ in the period $2010-2016$. The small percentage of managerial share ownership makes the manager as a shareholder get little benefit from the policies and risks they experience as a firm manager. This makes him/her less optimal in making policies that benefit majority shareholders because basically a manager has different interests as an owner and a controller of a company. If conditions as a shareholder are not profitable, then the manager prefers to be a decision maker.

\section{The Effect of Institutional Ownership on Firm Performance}

Based on the results of data analysis, institutional ownership had a positive impact on firm performance both on financial performance in the form of profitability and on market performance in the form of firm value in the manufacturing sector companies listed on the IDX. Significance value indicated that institutional ownership affected firm value with a positive correlation. That is, the more the number of shares owned by the institution was, the higher the firm value was. The result of this study is relevant to a study conducted by Abukosim et al. (2014) who found that institutional ownership had a positive effect on firm value. With the increasing percentage of institutional ownership in a company, there will be more voting rights and it encourages the institution to oversee management performance. As a result, it gives a greater impetus to be able to optimize firm performance so as to increase firm value. The result of this study supported by Thanatawee (2013) which showed a positive influence between domestic institutional ownership and firm value. This was because domestic institutional share ownership could provide an effective monitoring role, so it could improve firm governance and firm value. In this study the result showed that institutional ownership had a positive effect on firm value. This was due to the large average percentage of share ownership by the institutions. The average percentage of share ownership by institutions was $48.7 \%$ in the manufacturing companies listed on the IDX in the 2010-2016 periods. The size of the percentage made the institutions as policy makers more freely monitor firm management performance so that it could increase firm value

\section{The effect of capital structure on firm performance}

Capital structure had negative and significant effect on financial performance (ROA) in the manufacturing companies. In accordance with the theory of Brigham and Houston (2015), the higher the DER is, the greater the burden of a company to external parties is, this is very possible to decline firm performance because the level of dependence on external parties is higher. The higher the debt to equity ratio is, the higher the use of liability is as a source of firm funding. This can pose a considerable risk to the company when the company is unable to pay these obligations at maturity so that it will disrupt the continuity of firm operation. In addition, the company will be faced with high interest costs so that it can reduce firm profits. The result of this study is in line with the studies conducted by (Grossman \& Hart, 1982; Fama \& French, 2002; Pontoh \& Ilat, 2013; Hasan, Ahsan, Rahaman, \& Alam, 2014).

Based on the result of the study it can be seen that capital structure did not affect firm value in the manufacturing companies listed on the IDX. Significance value indicated that there was no significant effect of capital structure on firm value (MBV and Tobin's Q). That is, the changes in capital structure, either an increase or a decrease, could not affect firm value. Capital structure did not have an effect on firm value because basically in Indonesia the changes in stock prices are caused by market psychological factors. The amount of firm debt is not overlooked by investors; they are more likely to concern on how the firm manager uses the funds from the debt effectively and efficiently to achieve firm goals. Investors tend to invest in the companies that provide good value reflected in the stock price at that time rather than consider how much the percentage of capital and debt the company has. Besides, that the capital structure did not influence firm value can also be caused by the economic crisis in America in 2008. It has had the impact on capital markets throughout the world including in Indonesia. Then, the JCI (Composite Stock Price Index) decreased. The result of this study is not in 
line with the finding by (Antwi, Mills, \& Zhao, 2012) that the capital structure had a positive impact on firm value.

\section{The Effect of Control Variables}

Control variables in this study are liquidity, firm size, and economic growth. Liquidity is related to the ability of a business entity to fulfill its financial needs. The level of liquidity and the factors that influence it need to be considered by the internal company as a basis for determining policies for the development of a business entity from year to year. The level of liquidity for a company is to find out whether the company requires sufficient money to be used smoothly in carrying out its business. The level of liquidity for a company is to find out whether the company requires sufficient money to be used smoothly in carrying out its business. Saleem \& Rehman (2011) infers that liquidity has positive and significant effect on profitability. Further, liquidity no impact firm value, this research supported by Mahendra et.al (2012)

Firm size did not affect firm performance, either on ROA, MBV or Tobin's q, meaning that the changes in firm size, either the increase or the decrease could not affect firm value. This is because firm size measured by the natural logarithm of total assets does not reflect the actual value of the assets, so firm size cannot be a guarantee of good firm performance.

Economic growth (GDP) had positive and significant effect on firm performance, both on financial performance and on firm market performance. Economic growth can increase profitability. When GDP increases, society purchasing power automatically increases, so companies can produce more, which in turn will increase profitability. Furthermore, economic growth can also improve market performance or firm value. When GDP increases, society purchasing power automatically inreases, resulting in the increase in demand, then the increase in demand will increase stock prices so that firm value increases. The result of this study is in accordance with a theory put forward by Tandelilin (2007) which states that firm value is influenced by macroeconomic factors, one of which is economic growth. The result of this study is also in accordance with the findings by (Ang, 2010 ; Aggarwal \& Padhan, 2017).

\section{Conclusions}

Based on the results of the study and the discussion that have been carried out, it can be concluded that: there are various effects of ownership structure on firm performance. Managerial ownership has a positive effect on ROA, but does not affect market performance (MBV and Tobin's q). This shows that an increase in managerial ownership can affect ROA. It supports agency theory. What happens is that companies as agents prioritize their interest in optimizing firm profits so as to minimize the burden, including tax burden, by doing tax avoidance. Firm managers who are in power in companies for decision making as agents have their interest in maximizing the profits by issuing policies. Then, institutional ownership has a positive effect on firm market performance with MBV and Tobin's q indicators, but has no effect on ROA. With the increasing percentage of institutional ownership in a company, there will be more voting rights and it encourages institutions to oversee management performance. As a result, it gives a greater impetus to be able to optimize firm performance so as to increase firm value. Next, capital structure has a negative effect on ROA, but does not affect MBV and Tobin's q. The changes in capital structure, both an increase and a decrease, cannot affect firm value. This is supported by the pecking order theory. Pecking order theory prefers the funding from internal company rather than external company. There is no optimal capital structure in pecking order theory because the selection of firm funding is based on the order of preferences (hierarchy) of risk. In addition, liquidity as a control variable can affect ROA, but has no effect on MBV and Tobin's q. Furthermore, firm size does not affect firm performance, whereas economic growth can increase profitability and firm value.

And then this study shows empirical evidence that the ownership structure of institutions for investors as a basis for decision making in assessing a company to invest that will have an positive impact on the welfare of investors in the future. Furthermore, the results of this study indicate that 
the capital structure has negative affect on the company performance measured with profitability (ROA), but does not affect the company performance measured using company value (MBV and Tobins'Q). This shows that an increase corporate debt will have a negative impact on company performance. This is happen because of investors tend to invest on companies that has a high value where it is reflected in stock price in the market, rather than how much the debt of the company has.

\section{References}

Abor, J. (2005). The effect of capital structure on profitability: an empirical analysis of listed firms in Ghana. The Journal of Risk Finance, 6(5), 438-445.

Abukosim, Mukhtaruddin, Ferina, I. S., \& Nurcahaya, C. (2014). Ownership Structure and Firm Values: Empirical Study on Indonesia Manufacturing Listed Companies. Journal of Arts, Science $\mathcal{E}$ Commerce, 5 (4), 1-14.

Akintoye, IR. (2016). Investment Decisions in the 21st Century. Unique Educational Publishers: Lagos, Nigeria.

Amjed, S. (2011). Impact of Financial Structure on Firm's Performance: A Study of Pakistan's Chemical Sector. Society of Interdisciplinary Business Research (SIBR) 2011 Conference on Interdisciplinary Business Research, https://ssrn.com/abstract=1867882.

Aggarwal, D., \& Padhan, P. C. (2017). Impact of Capital Structure on Firm Value: Evidence from Indian Hospitality Industry. Theoretical Economics Letters, 982-1000.

Al-Matari, E. M., Al-Swidi, A. K., \& Fadzil, F. H. (2014). The Measurements of Firm Performance's Dimensions. Asian Journal of Finance \& Accounting, 6(1), 24-49.

Antwi, S., Mills, E. F., \& Zhao, X. (2012). Capital Structure and Firm Value: Empirical Evidence from Ghana. International Journal of Business and Social Science, 3(22), 103-111.

Ang, R. (2010). Buku Pintar Pasar Modal Indonesia (7 ed.). Jakarta: Media Soft Indonesia.

Bayrakdaroglu, A., Ersoy, E., \& Citak, L. (2012). Is There a Relationship Between Corporate Governance and Value-based Financial Performance Measures? A Study of Turkey as an Emerging Market. Asia-Pacific Journal of Financial Studies, 41, 224-239.

Brigham, E. F., \& Houston, J. F. (2015). Fundamentals of Financial Management (14 ed.). United States: Cengage Learning, Inc.

Chiang, Y. H., Albert, P. C., \& Eddie, H. M. (2002). Capital structure and profitability of the property and construction sectors in Hong Kong. Journal of Property Investment and Finance, 20(6), 434453.

Claessens, S., Djankov, S., \& PLang, L. H. (2000). The separation of ownership and control in East Asian Corporations. Journal of Financial Economics, 58(1-2), 81-112.

Claessens, S., Djankov, S., Fan, J., \& Lang, L. H. (2002). Disentangling the incentive and entrenchment effects of large shareholdings. Journal of Finance, 57(6), 2741-2771.

Collin, S.-O., Smith, E., Uman, T., \& Broberg, P. (2013). Mechanisms of corporate governance going international: Testing its performance effects in the Swedish economy, 2004. Baltic Journal of Management, 8(1), 79-101.

Dada, A. O., \& Ghazali, Z. B. (2016). The Impact of Capital Structure on Firm Performance:Empirical Evidence from Nigeria. IOSR Journal of Economics and Finance (IOSR-JEF), 7(4), 23-30.

Darwazeh, R. N., \& Dabaghia, M. (2018). Privatization Effect on Shareholder Value in the Jordanian State. International Journal of Economics and Financial Issues, 8(2), 70-78.

Demsetz, H., \& Villalonga, B. (2001). Ownership structure and corporate performance. Journal of Corporate Finance, 7, 209--233. 
BIBLIOGRAPHY \l 1057 Douma, S., George, R., \& Kabir, R. (2003). Foreign and Domestic Ownership, Business Groups and Firm Performance: Evidence from a Large Emerging Market. Available at SSRN: https://ssrn.com/abstract=685783 or http://dx.doi.org/10.2139/.

Demsetz, H. (1983). The structure of ownership and the theory of the firm. Journal of Law and Economics, 26, 375-390.

Dobak, M. (2006). “Corporate governance in Central and Eastern Europe. Society and Economy, 8(1), $27-40$.

Ebaid, I. E.-S. (2009). The impact of capital-structure choice on firm performance: Empirical evidence from Egypt. Journal of Risk Finance, 10(5), 477-487.

Fama, E. F., \& French, K. R. (2002). Capital Structure Choices. Critical Finance Review, 1, 59-101.

Gambo, E.-M. J., Ahmad, A. -R., \& Musa, A. M. (2016). Capital Structure and Firm Performance in the Nigerian Cement. Archives of Business Research, 4(6), 30-44.

Gill, A., \& Nahum, B. (2011). The effect of capital structure on profitability.evidence from the United States. International Journal of Management, 28(4), 3-15.

Gleason, K. C., Mathur, L. K., \& Mathur, I. (2000). The Interrelationship between Culture,Capital Structure, and Performance: Evidence from European Retailers. Journalof Business Research, 50, 185-191.

Goddard, J., Tavakoli, M., \& Wilson, J. O. (2005). Determinants of profitability in European manufacturing and services: evidence from a dynamic panel model. Applied Financial Economics, $15,1269-1282$.

Ghosh, A., Cai, F., \& Li, W. (2000). The Determinants of Capital Structure. American Business Review, 18(2), 129-132.

Grossman, S. J., \& Hart, O. D. (1982). Corporate financial structure and managerial incentives. The economics of information and uncertainty. University of Chicago Press, 128-146.

Hadlock , C. J., \& James, C. M. (2002). Do Banks Provide Financial Slack? The Journal of Finance, 57(3), 1383-1419.

Harjanto. (2015). Membedah Potensi Industri di Indonesia. Jakarta: Universitas Indonesia.

Hasan, M. B., Ahsan, A. M., Rahaman, M. A., \& Alam, M. N. (2014). Influence of Capital Structure on Firm Performance: Evidence from Bangladesh. International Journal of Business and Management, 9(5), 184-194.

Hermalin, B., \& Weisbach, M. (1991). The Effects of Board Composition and Direct Incentives on Firm Performance. Financial Management, 20(4).

Hossain, M. (2016). Effects of Capital Structure and Managerial Ownership on Profitability: Experience from Bangladesh. International Journal of Business and Management, 11(9), 2018-229.

Hung, C. Y., Albert, C. P., \& Eddie, H. C. (2002). Capital structure and profitability of the properti and construction sectors in Hongkong. Jornal of Property Investment \& Finance, 20(6), 434-543.

Ibrahim, H., \& Samad, F. A. (2011). Corporate Governance Mechanisms and Performance of PublicListed Family-Ownership in Malaysia. International Journal of Economics and Finance, 3(2), 105115.

Jones, D. C., Kalmi, P., \& Migind, N. (2005). "Choice of ownership structure and firm performance:evidence from Estonia. Post-Communist Economies, 17(1), 83-107.

BIBLIOGRAPHY $\backslash 11057$ Kapopoulos, P., \& Lazaretou, S. (2007). Corporate Ownership Structure and Firm Performance: evidence from Greek firms. Corporate Governance: An International Review, 15(2), 144-158. 
Khan, A. G. (2012). The relationship of capital structure decisions with firm performance: A study of the engineering sector of Pakistan. International Journal of Accounting and Financial Reporting, 2(1), 245-262.

Kyereboah-Coleman, A. (2007). The impact of capital structure on the performance of microfinance Institutions. The Journal of Risk Finance, 8(1), 56-71.

Mahendra DJ, A., Artini, LGS, and Suarjaya, AG. (2012). The influence of the financial performance of the company's value in manufacturing companies in Indonesia Stock Exchange. Matrix: Journal of Management, Business Strategy and Entrepreneurship

Majumar, S. K., \& Chhibber, P. (1999). Capital structure and performance: Evidence from a transition economy on an aspect of corporate governance. Public Choice, 98, 287-305.

Margaritis, D., \& Psillaki, M. (2010). Capital structure, equity ownership and firm performance. Journal of banking and Finance, 34(3), 621-632.

BIBLIOGRAPHY \1 1057 McConnell , J., \& Servaes, H. (1990). Additional evidence on equity ownership and corporate value*. Journal of Financial Economics, 27, 595-612.

Nenu, E. A., Vintila, G., \& Gherghina, S. C. (2018). The Impact of Capital Structure on Risk and Firm Performance: Empirical Evidence for the Bucharest Stock Exchange Listed Companies. International Journal of Financial Studies, 1-29.

Nunes, P. J., Serrasqueiro, Z. M., \& Sequeira, T. N. (2007). Profitability in Portuguese service industries: a panel data approach panel. The Service Industries Journal, 29(5), 693-707.

Obembe, O. B., Olaniyi, C. O., \& Soetan, R. O. (2016). Managerial ownership and performance of listed non-financial firms in Nigeria. Int. J. Business and Emerging Markets, 8(4), 446-460.

Onaolapo, A. A., \& Kajola, S. O. (2010). Capital structure and firm performance: Evidence from Nigeria. European Journal of Economics, Finance and Administrative Sciences.

Pontoh, W., \& Ilat, V. (2013). Determinant Capital Structure and Profitability Impact (Study of Listed Company in Indonesian Stock Exchange). Research Journal of Finance and Accounting, 4(15), 4350 .

Pratheepan, T., \& Banda, Y. W. (2016). The Determinants of Capital Structure: Evidence from Selected Listed Companies in Sri Lanka. International Journal of Economics and Finance, 8(2), 94-106.

Rao, Narendar, V., Al-Yahyaee, Mohamed, K. H., Syed, \& Lateef, A. M. (2007). Capital Structure and Financial Performance: Evidence from Oman. Indian Journal of Economics and Business.

Sadeghian, N. S., Latifi, M. M., Soroush, S., \& Aghabagher, Z. T. (2012). Debt Policy and Corporate Performance: Empirical Evidence from Tehran Stock Exchange Companies. International Journal of Economics and Finance, 4(11), 217-224.

Saona, P., \& San Martín, P. (2016). Country level governance variables and ownership concentration as determinants of firm value in Latin America. International Review of Law and Economics, 47, 84-95

Saleem, Q., \& Rehman, R. U. (2011). Impacts of liquidity ratios on profitability. Interdisciplinary Journal of Research in Business, 1(7), 95-98.

Singh, B., \& Singh, M. (2016). Impact of Capital Structure on Firm's Profitability: A Study of selected listed Cement Companies in India. Pacific Business Review International, 8(7), 46-54.

Singh, S., \& Singh, A. (2018). Study on the Relationship of Firm's Performance with Capital StructureEvidence from Taiwan. International Journal of Economics and Financial Issues, 8(3), 307-314.

Sujoko, \& Soebiantoro, U. (2007). Pengaruh Struktur Kepemilikan saham, Leverage, Faktor Intern dan Faktor Ekstern terhadap nilai perusahaan. Journal Manajemen dan Kewirausahaan, 9, 41-48.

Tandelilin, E. (2007). Analisis Investasi dan Manajemen Portofolio. Yogyakarta: PT.BPFE. 
Thanatawee, Y. (2013). Ownership Structure and Dividend Policy: Evidence from Thailand. International Journal of Economics and Finance, 5(1), 121-132.

Wahla, K. U.-R., Shah, S. Z., \& Hussain, Z. (2012). International Research Journal of Finance and Economics. Impact of Ownership Structure on Firm Performance Evidence from Non-Financial Listed Companies at Karachi Stock Exchange(84), 6-13.

BIBLIOGRAPHY \11057 Yeoh, P. (2007). The direction and control of corporations: law or strategy? Managerial Law, 49(1/2), 37-47.

Zhuang, J., Edwards, D., \& Capulong, M. V. (2001). Corporate Governance and Finance in East Asia. Manila, Plilippines: Asian Development bank. 